\title{
Political Leadership in Policy Implementation: Case Study of Rural Transport Accessibility in Kuala Krai, Kelantan, Malaysia
}

\author{
Maria Mohd Ismail (Corresponding author) \\ Department of Administrative Studies and Politics, \\ Faculty of Economics and Administration, \\ University of Malaya, 50603 Kuala Lumpur, Malaysia \\ E-mail: maria_may1910@yahoo.com \\ Associate Professor Dr. Raja Noriza Raja Ariffin \\ Department of Administrative Studies and Politics, \\ Faculty of Economics and Administration, \\ University of Malaya, 50603 Kuala Lumpur, Malaysia \\ E-mail: rnoriza@um.edu.my
}

Received: Nov. 19, 2020 Accepted: Dec. 17, 2020 Online published: Jan. 15, 2021

doi:10.5296/jpag.v11i1.17961ＵRL: https://doi.org/10.5296/jpag.v11i1.17961

\begin{abstract}
Politics plays a major role in every aspect of the government development plan. Kelantan is an interesting case in understanding the different political leadership involved in the implementation process. This study reports how politics influenced the development of rural transport accessibility in Kuala Krai, Kelantan. In-depth interviews were conducted among 33 respondents; 13 policymakers from the federal, state and local level and 20 villagers covering all the three sub-districts in Kuala Krai, Kelantan, Malaysia. The findings were presented based on the emerging themes emerged from the analysis. The findings confirmed that politics is the primary mover in formulating and implementing any transport accessibility plan in the study area. The findings also provided ultimate insights for policymakers at multiple decision-making level involved in formulating and implementing for an accessible rural transport system for the rural communities.
\end{abstract}


Keywords: rural transport, accessibility, political leadership, implementation, politics

\section{Introduction}

\subsection{Political Perspective in Policy Implementation}

The political perspective in the context of public policy recognises that governmental decisions are certainly based on the value it can gain. Thus, power under the political perspective is commonly used in protecting interests as well as positions on how policy problems and solutions are defined (Bekkers, Fenger \& Scholten, 2017). The policy process is commonly defined through the political strategies proposed by the actors involved (Baumgartner \& Jones, 1993). Consequently, the policy processes occur in an arena or in different places that are often linked together (Lasswell, 1958; Lowi, 1964; Allison \& Zelikow, 1971; Crozier \& Friedberg, 1980). The mentioned arenas involve a power-driven interaction such as negotiation, coercion, persuasion, and compromise situations involving different actors that practice their political strategies in safeguarding their interests.

In light to this scenario, scholars argued that often political approach involved in policy processes always deal with continuous struggle between different, competing values (Lindblom, 1965). Conflicts of interests shaped the policy process, rather than harmonious problem solving as the power conflicts and political strategies of the stakeholders often shaped the development, decision-making and implementation of policy processes. Again, stated by the scholar, stakeholders need power in influencing public policies. The ability of one actor to influence other actors' behaviors is part of power (Dahl, 1961). Meanwhile, in the viewpoint of politics, human behavior is very much guided by self-interest. Thus, it is important to balance the actors' self-interests and the general interest in a public policy process. However, the general interest appears to be unclear on how it can be pursued from a political perspective (Bekkers, Fenger \& Scholten, 2017).

In understanding how political discourse involves in the context of public policy, one should also consider the element of political culture. Political culture is defined as "the cluster of distinctive shared political values, attitudes, beliefs and orientations". The cluster as defined above is related to the values as well as behavior of people and institutions. The values or mores as called by the scholar is significant for the survival of the society. Hence, to better understand political culture, Leeds (1981) suggests two-way process that involves (I) the underlying political culture that govern political behavior and the development of institutions; (2) in a reverse direction, the existing political system acts as a conditioning factor, influencing the boundaries which the political culture exists. Political culture on the other aspect has a significant element in stabilizing a state's political system and leadership (Bowring, 2004).

\subsection{Problem Statement}

In the case of Malaysia, politics is seen as the primary mover that intervenes in every aspect of the government development plan including in the policy formulation and implementation process. The major roles of politicians in influencing the policy process in Malaysia is commonly known. In the case of transport planning, the power play among the government 
agencies in the state are seen as one of the ultimate reasons why most of the rural transport plan failed to be implemented besides fiscal insecurity of the opposition state. Political interest has driven away the initiated policy intentions which in return caused divergent of policy actual intentions and unable to solve the revealing rural transport issues in the area. The bottom-uppers once stated that "In this sense policy may become a substitute for action, to demonstrate that something is being done without actually tackling the problem" (Barrett \& Fudge, 1981:276).

In the context of Malaysia, transport is only recognised when it brings a positive impact on economic development (Raja Noriza, 2006). Consequently, to comprehend the development and implementation of a certain policy, it is fairly significant to digest the political environment of a particular country especially in terms of its political system, aspirations, values, and beliefs. Raja Noriza (2006) further added that transport policy can be categorized as those policies that are much more difficult to carry out with objective identification and measurement. This is because transport policy outcomes have to be understood in the context of being the product of different streams of policies that interact, compete, and contradict each other. As a result, the task of identifying and measuring standards and objectives is almost impossible.

As stated by Marsden et al (2011), politics affects how relationships between governmental sectors are built. In formulating public policies, collaboration of various stakeholders is needed as well as coordination among inter-departments and levels of government. These relations are very much influenced by formal and informal institutions including political relations (Nice, 1987). Having said that, Kelantan is an interesting case of understanding political leadership due to the different political belief and culture in the state. The different political relation with the federal government allows an opportunity to better understand the political leadership represent by the local political parties in implementing rural transport plan.

Being one of the poorest states in Malaysia with a different political ideology, it is even more interesting to understand the transport accessibility scenario in the study area and how does political leadership hinder the implementation of rural transport initiatives. As reported in the Kuala Krai Local Plan (2010-2020), the present road system in Kuala Krai, Kelantan is incomprehensive as some villages in the area are still not connected with a proper road system. Being reported to have a poor transport system has made the study to be rather challenging as to explain the reason transport accessibility in the study area is inefficient and poor despite having solid transport plans in the government development plans, particularly in the rural areas. Ngah (2015) argued that lack of political will to decentralize planning activities at local levels and failure to incorporate a bottom-up approach in planning has limited most of the implementation process in Malaysia. He further added that rural policies and planning mechanisms at the regional and local levels in Malaysia are lacking. 


\subsection{Literature Review}

\subsubsection{Political Leadership}

Politics is also commonly linked with leadership traits. This includes individual personal values, styles, and behaviors. A leader is defined as an individual who has some degree of power and authority granted through multiple sources. Thus, a leader is commonly pictured as an individual with power or influence that is capable to persuade others in changing their preferences or actions (Mohammed, N. 2007). Similar to managerial leadership, political leadership deals with specific communication skills in dealing with people and the related circumstances (Fradette \& Michaud, 1998). Besides having sophisticated skills in communicating and dealing with people, political leadership must also be able to describe leadership roles in any related institutional setting or political system. Every role has its own defined tasks and responsibilities that need to be exercised. In exercising the roles, an individual may either perform it individually or collectively that involves the relationship with others. A strong relationship in political leadership is very much determined by the present actors or the previous ones as stated by Paige (1977).

In light to the above statements, Afegbua and Adejuwon (2012) highlighted that it is a challenging attempt to define the meaning of leadership, or what makes certain persons possess leadership qualities. For example, some researchers define leadership in terms of personality and physical traits, while others believe leadership is represented by a set of prescribed behaviors. Robert et al. (2004) affirm that leadership involves a complex interaction among the leader, the followers, and the situation. As cited by Madinah Mohamad, Abu Daud Silong and Zaharah Hassan (2008), according to a study conducted by the University of Iowa, leadership behavior ranges from autocratic to democratic to laissez-faire behaviors. Autocratic leaders are those emphasising on centralized power, while democratic leaders are more participative in nature. Laissez-faire leadership is considered non-leadership because there is little guidance provided.

In the Malaysian context, Madinah Mohamad et al. (2008) found the democratic style that involves two-way interaction is the most effective for a multiracial community. Recent events indicate that the leadership style in the Malaysian public sector needs to change. In the past, leadership in the Malaysian public sector has always relied on a strong authoritarian style. Apparently, to remain relevant in the 21 st century, the leadership style has to change to a more collaborative and participative style (Abu Daud Silong, 2008; Tam, 2008).

\subsubsection{Rural Transport Accessibility}

The role of transport is to ease the access people have to goods, services, and facilities as improved transport access reduces isolation. People need to have access to a wide variety of goods, services, and facilities to live a productive life. An improved transportation system results in faster, safer, cheaper, more reliable, and comfortable travel for people and products. Porter (2013) highlighted that lack of affordable rural transport also prevented people from having proper access to schools, clinics, hospitals, markets, and other social services.

According to Tsumagari (2007), a weak transportation system in rural areas is acknowledged 
to be an ultimate constraint on development and an important contributor to poverty in many regions. It is not possible to operate transport services without strong infrastructure as it affects transport availability and operating costs. The disproportionate emphasis on infrastructure development is evident in the percentage of countries seeking loans from the World Bank, where $98 \%$ of rural transport lending is for road building and maintenance purposes. Thus, poor accessibility is believed to contribute to the economic recession as well as deprivation in rural areas as once stated by Sarkar and Ghosh (2000).

\subsubsection{Brief History of BN-PAS Political Practice in Kelantan}

Malaysian politics and socioeconomic structures have always been viewed as plural, communal, and sometimes divided (Weiss, 2003; Case, 1995; Jesudason, 1995; Crouch, 1992; Milne \& Mauzy, 1986). However, the political and economic momentum has been steadily supporting inter-ethnic relations between the Malay, Chinese and Indian populations. Right after independence in 1957, the political landscape in Malaysia evolved and focused on forging better alliances among the three major parties specifically, the United Malays National Organization (UMNO), the Malaysian Chinese Association (MCA), and the Malaysian Indian Congress (MlC). The alliance was called Perikatan and later changed its name to Barisan Nasional (BN) in 1973 (Case, 1995).

The first period of PAS rule in Kelantan began two years after independence, in 1959. The interval between the two periods of PAS when the Barisan Nasional Party ruled the state for 12 years (11 March 1978 to 21 October 1990). In the 1990 General Election, PAS returned with an overwhelming victory, winning all the 39 State and 13 Parliamentary seats (Commonwealth Parliamentary Association, 2019). Kelantan has been ruled by the Islamic Party of Malaysia (PAS) since 1990 with re-elections in 1995, 1999, and 2004. It is one of the Malaysian states that is not ruled by the Barisan Nasional coalition after the 2008 elections. Almost all PAS members are Malay Muslims, as are about $95 \%$ of Kelantan's population. Kelantan is almost synonymous with PAS as Kelantan has been ruled by PAS for more than 27 years from now.

\section{Method}

This study uses a qualitative case study approach. In-depth interviews were conducted among 33 respondents; 13 policymakers from the federal, state and local level and 20 villagers covering all three sub-districts in Kuala Krai. The intent of the qualitative research is to obtain an in-depth understanding of the subject of study with closer emphasis on individual views by interviewing and observing them. Hence, it allows researcher to study the phenomenon in its natural setting in order to understand the multiple realities based on the meanings people bring to them (Denzin \& Lincoln, 2005). Further supporting this argument, Creswell (2009) stated that qualitative research closely explores the respondents' opinions in describing and explaining on the social or human problem. In this case study, prior explaining the challenges in implementing the existing rural transport plan in the study area, it is ultimately significant to first understand the actual transport accessibility issues experienced by the villagers. The current state of transport accessibility in the study area is further explain through in-depth interviews conducted among the villagers. 
A semi-structured interview protocol is used to guide the overall in-depth interview process. The interviews conducted were ethically aligned with the university ethical procedures and had obtained informants 'consents prior conducting the interviews. Informants' identities were kept confidential and their names were replaced with alphabetical codes such as PM for policymakers, KKV for Kuala Krai villagers and GK for gatekeepers. Politics was one of the main emerging themes emerged in the analysis and remained as one of the most significant challenges in implementing a successful rural transport plan. Rural transport accessibility scenario in other rural areas in Malaysia might be different from the study context and therefore the outcome of this study is not meant for generalization of the overall rural transport accessibility phenomenon in the Malaysian context. However, this study is to further explain and understand on how the political leadership influence the implementation of rural transport plan in the study area from the policymakers and villagers 'perspectives respectively.

\section{Results}

This section looks at the empirical findings obtained from the interviews. The interview data managed to capture comprehensive insights from the policymakers from the three levels of government (federal, state, and local) as well as the villagers in Kuala Krai, Kelantan. The data presented a rich strand of information and this section further unfold and explore the different opinions shared among the respondents.

\subsection{Power and Influence}

Political influence is rather critical in the rural areas as it heavily influenced the overall development of the area. Political elected representatives are the backbones in the rural areas as they are the ones who demand for development in their areas. An active political leader would demand for development and take care of the well-being of his/her supporters and vice versa. An interviewee put it in general as such:

“...the role of political leaders is important in any of the rural area.” (PM_5)

Another federal government transport top officer offered the same opinion and put forward his explanation as such:

"...oh yes for sure. In the system of democracy, the political will is the most important thing. If you have the political will, you want to change something then you'll have it. Otherwise, nothing will happen.” (PM_3)

Meanwhile, there are policymakers with the opinions that rural areas under the leadership of the ruling political party would benefit the most. Especially in the case of Kelantan, where there are some rural areas governed by the state dominant political party (PAS) and the country ruling political party, Barisan Nasional (BN). Areas under the BN leadership is said to develop prosperously compared to the areas under the administration of PAS. A local government policymaker has this to offer:

"...for rural area it is important for us to be under the federal political party as it is easier to get funds. As for example in Gua Musang, Kelantan is governed by the 
Barisan Nasional (BN) and that's why we can see development in there. If it is governed by PAS, nothing will happen.” (PM_9)

A federal government agency officer in Kelantan concluded the power play influenced by political interest as:

“...politics, sometimes it gives positive impacts and sometimes negative.” (PM_13)

\subsection{Poor Leadership}

Contradict with the statements given by the local government policymakers on the benefit of being under the federal ruling party, at that time (2018) it was Barisan Nasional (BN), many of the villagers in Kuala Krai voiced their frustrations under the administration of BN. The injustice and unfairness way of ruling were among the criticized actions of BN mentioned by the villagers. Interestingly, most of the villagers strongly believed that PAS is rather relevant in ruling the rural areas although PAS has nothing much to offer (financially). However, the attitudes of PAS political leaders of being humble, kind and caring had won the villagers' hearts with no hesitation according to most of the villagers. A local villager put forward her frustration over BN leadership as such:

“... he (BN political leader) only visited us before the election. He wanted to allocate street lamp posts but in doing so, he urged villagers to support him first. Most of the offers (facilities) are like that. We need to support him first in order to get the facilities." (KKV_1)

Will to implement a policy is vested on the actors who have the power to change plans into actions. In a simple word, will is the desire to implement strategies or plans into actions. Role of politicians is critical in realizing formulated plans into real actions. Politicians are the ones that actually made policies happened. Most of the opinions shared by the interviewees regarding rural transport plans in Kuala Krai, Kelantan was on the will to implement such plans into actions.

Numerous plans (e.g., Rural Physical Plan, Malaysian Plan, State Structure Plan and Local Plan) have been formulated specifically focusing on the provision of public transport in the rural areas, uplifting the rural infrastructures like roads, bridges, and other facilities. However, despite having such remarkable plans and strategies, that masterpiece remained in writings as most of the initiated plans failed to be implemented as according to the policymakers. Although financial is the major culprit in implementing most of the development plans, yet it should not be the only reason why politicians or even policymakers are not working hard enough in demanding for better development in their respective areas especially the remote areas. According to a federal government policymaker:

“...the politician represents the people, so if you don't do your job properly at the end of the day the public will suffer." (PM_3)

Consequently, separation of power has also appeared to be one of the reasons that weaken the effectiveness of rural transport plan implementation. Again, this separation or division of power is very much related to the political factors discussed earlier. Problem happens when it 
comes to who has the actual power in deciding for everything. However, some leaders were said not to utilize the power they had in benefiting the people, instead, some used the power vested on them for their own purposes and benefits. A state government planner has this to say regarding this scenario:

"...to me, the leader or the politicians are the one who supposed to coordinate everything. They are the ones that have connections with the ministries or even the Prime Minister. Their networking is wider and they are supposed to utilize such power usefully. Unfortunately, not all are using it right...most are according to their preferences that would benefit them." (PM_4)

Despite the political party backgrounds, an active politician would demand for rapid development in his or her area. Since politician is described as development mover for an area especially in the remote area, dynamic approach and strategy in engaging community to develop their areas are significant. However, failure in capturing the needs of the people and the ability to serve them would negatively impact the people in general. A federal government policymaker wrapped up the role of a politician as such:

"...active politicians will demand for more development and more projects, vice versa." (PM_1)

\subsection{Participative Leadership}

Since Kelantan is ruled by a different political party (PAS) than the federal government, the villagers are having a hard time in demanding for basic facilities in their villages according to the villagers. Although it has been said that rural area should best ruled by the federal ruling party, however, such power play in the remote areas is almost non-existent. Alas, villagers who lived across the river did not benefit much facilities as promised by the political leaders in their manifestos.

Most of the villagers were frustrated with the way BN political leaders treated them as most of their promises made during the election were not fulfilled. Villagers seemed more satisfied with PAS leadership and did not blame the party of not providing most of the basic facilities due to the shortage of money. A villager who was a loud supporter of BN political party expressed his anger over the party injustice. His frustration is put forward as follows:

“... supposedly, BN political elected headman (JKKKP) should help the villagers but he failed to do so. If he had any allocations, he will give to his family and relatives first although they do not need it. Different with PAS, they do not have enough budget. BN has to change their attitude and culture as they received direct allocation from the federal and they are held responsible to give out the allocations accordingly. During the big flood in 2014, rice aid was only given to BN's families. We the villagers, we cooked and eat together." (KKV_15)

In the case of Dabong, a remote area in Kuala Krai, Kelantan, PAS (state ruling party) political leader used a rather different approach in managing matters in the rural area by engaging the villagers to work together as a team in managing any activities such as road 
fixing, landslides cleaning and other related activities in the district. His cooperative approach had allowed villagers to develop stronger bonds among themselves and created sense of belongings among the villagers. He devotedly expressed his determination as such:

“.... in any project, I'll use my own money first... as it would take a longer time to receive state allocation. I'll buy the needed things and asked the villagers to engage with each other and work together in fixing almost everything such as roads. I will then ask the village headman to send official letter to the Chief Minister's office, stating that we need to encounter problems urgently and so we are using our own budget and would claim later. Once the Chief Minister approved, we quickly perform the task." (GK_3)

Such determination shown by PAS leader has gained attention from the local government policymakers and most of the villagers. A local government officer put forward his compliment as follows:

“...I think PAS leaders are very active.” (PM_8)

\section{Discussion}

\subsection{Power and Influence}

The major role of politicians in influencing the policy process in Malaysia is commonly known. As mentioned by the interviewees, the elected politicians have extensively used their political power and influence either formally or informally under the administrative hierarchy. The practice is said to be obvious in the rural settings especially in the opposition states where the dominant political party, BN was in power. The dominating political power of BN has widely influenced Kelantan's authority structure as well as at the local government level that has wider implications in the policy process.

In Kuala Krai, the power and influence of the elected political leader have overwhelmed the district development. It has been confirmed by the interviewees that the application of a bridge in Pasir Klang, an area in Kuala Krai, was only approved recently. The bridge has been demanded by the villagers since 1998 to ease the accessibility and mobility of approximately more than 2000 lives across the river in performing their daily activities. "...politics is our system ...the bridge was only approved once it was politicised..." (PM_10).

The power play among the government agencies in Kelantan are seen as one of the ultimate reasons most of the rural transport plan has failed to be implemented effectively besides fiscal insecurity of the opposition state. Political interest has overpowered the initiated policy intentions which in return caused a divergence of policy actual intentions and lead to the government's inability to solve the revealing rural transport issues in Kuala Krai. The bottom-uppers once stated that "In this sense policy may become a substitute for action, to demonstrate that something is being done without actually tackling the problem" (Barrett \& Fudge, 1981:276). 


\subsection{Political Culture in Kelantan}

In the case of Kelantan, PAS's Islamic political framework has shaped and influenced the political culture in the state for 27 years now. PAS's popularity in the state is undeniable and unbeatable as the party has successfully won the hearts of the majority Kelantanese in spreading and practicing Islamic ideology. However, in the case of Kuala Krai, several of the interviewed policymakers were of the opinion that rural areas should be administered by BN to ease fiscal assistance. The rural areas were said to have a better and faster development phase when ruled by the Barisan Nasional (BN). One of them said "...Gua Musang, Kelantan is governed by the Barisan Nasional (BN) and that's why we can see development in there. If it is governed by PAS, nothing will happen..." (PM_9). While the other policymaker mentioned that "...it is easier for the party $(B N)$ to bring in allocations..." (PM_11). The role of politicians is said to be important in demanding budgets as confirmed by the policymakers during the interviews.

Interestingly, the needs of having an influential politician in rural areas as agreed by the policymakers at the federal, state, and local levels somewhat contradict the actual scenario in Kuala Krai. The majority of the villagers voiced their frustration and disappointment towards Barisan Nasional (BN) in ruling the rural areas in Kuala Krai. During the interviews, the villagers acknowledged the political injustice practiced by BN in Kuala Krai. Surprisingly, not only the non-supporters of BN clarified the dissatisfaction towards the party, but the loyal supporters of the political party also acknowledged the injustice shown by the party. Many of them mentioned that "...BN political elected headman (JKKKP) should help the villagers but... if he had any allocation, he would give to his family and relatives first..." (KKV_15).

The BN political leaders were said to be present only during the pre-elections and were hard to reach if ever the villagers visited them in the office or whenever they needed the political representative to visit their villages to witness their poor living conditions. One of the loyal supporters of BN burst into tears when the party failed to keep its promise in replacing the villagers' water restoration tanks that had been applied for 3 years. He said in disappointment "...from 2015 to 2018, he (the political representative) has never come even once to visit our village and witness himself the condition of our village..." (KKV_4).

To understand the policies and actions of stakeholders in a country, one has to understand the environment that sets the underlying principle. Several writers have highlighted the wider and more diffuse political setting within which implementation takes place (Hood 1976; Sabatier \& Mazmanian 1979; Parsons 1995; Hill 1997). Hood (1976:193) concluded that "in none of the cases which we have studied was an administrative failure divorced from political maneuvering." Consequently, politics can play an important role in this discretion and can mold the intra and inter-governmental coordination in a public policy process (Oliveira, 2016).

\section{Acknowledgments}

My sincere gratitude to the respondents to the policymakers and the villagers who were willing to participate in this study in sharing their knowledge and experience. The villager's 
sincerity in welcoming me to their village and the hospitality they provided during my stay in Kuala Krai are greatly appreciated and will never be forgotten. This article is self-sponsored and is originally written by the corresponding author and reviewed by the co-author.

\section{References}

Afegbua, S. I., \& Adejwon, K. D. (2012). The challenges of leadership and governance in Africa. International Journal of Academic Research in Business and Social Sciences, 2(9), $141-157$

Allison, G., \& Zelikow, P. (1971). The Essence of Decisions: Explaining the Cuban Missile Crises. Boston: Little Brown \& Co.

Barrett, S., \& Fudge, C. (1981). Policy and Action: Essays on the implementation of public policy. Methuen, London.

Baumgartner, F. \& B. Jones (1993). Agendas and Instability in American Politics. Chicago, IL: Chicago of University Press.

Bekkers, V., Fenger, M., \& Scholten, P. (2017). Public policy in action: Perspectives on the policy process. United Kingdom: Edward Elgar Publishing

Bowring, P. (2004, July 13). Philip Bowring: When the Malays cast their votes. International Herald Tribune Online.

Case, W. (1995). Malaysia: Aspects and audiences of legitimacy. In M. Alagappa (Eds.), Political legitimacy in South East Asia (pp. 69-107). California: Stanford University Press.

Commonwealth Parliamentary Association (2019). The parliament of Kelantan, Malaysia. Retrieved from http://www.cpahq.org/cpahq/core/parliamentinfo.aspx?committee=Kelantan.

Creswell, J. W. (2009). Research design: Qualitative, quantitative and mixed methods approaches ( $3^{\text {rd }}$ ed). California: SAGE Publications, Inc.

Crouch, H. (1992). Authoritarian trends, the UMNO split and the limits to state power. In Joel S. Kahn \& Francis Loh Kok Wah (Eds.), Fragmented vision: Culture and politics in contemporary Malaysia (pp. 21-43). Sydney: Allen and Unwin.

Dahl, R. (1961). Who governs? Power and democracy in an American City. New Haven, CT: Yale University Press.

de Oliveira, J. A. P. (2016). Bridging governmental relations in urban management: Cases of solid waste management and climate change in two Malaysian states. MIT-UTM Malaysia Sustainable Cities Program, 1-24.

Denzin, N. K., \& Lincoln, Y. S. (2005). Introduction: The discipline and practice of qualitative research. In N. K. Denzin \& Y. S. Lincoln (Eds.), The Sage handbook of qualitative research (3rd ed.) (pp. 1-32). Thousand Oaks, CA: Sage.

Fradette, M., \& Michdaud, S. (1998). The power of corporate kinetics: Create the self-adapting, self-renewing, instant-action enterprise. New York: Simon and Schuster. 
Hill, M. (1997). The policy process in the modern state $\left(3^{\text {rd }}\right.$ ed). London: Prentice Hall.

Hood, C. C. (1976). The limits of administration. London: Wiley.

Kelantan State Structural Plan (2010-2020). Perpustakaan Negara Malaysia. Retrieved 10, February, 2018 from https://sgp1.digitaloceanspaces.com/proletarian-library/singapore-malaysia

Leeds, C. A. (1981). Political studies (3rd ed.). Plymouth: Macdonald \& Evans.

Leswell, H. D. (1958). Politics: Who gets what, when how. New York: Meridian Books.

Lowi, T. J. (1964). American business, public policy, case studies and political theory. World Politics, 16(4), 677-715. https://doi.org/10.2307/2009452

Marsden, G., Frick, K. T., May, A. D., \& Deakin, E. (2011). How do cities approach policy innovation and policy learning? A study of 30 policies in Northern Europe and North America. Transport Policy, 18, 501-512. https://doi.org/10.1016/j.tranpol.2010.10.006

Mohammed, N. (2007). Leadership and political culture: A brief look at the Malaysian political landscape. Journal of Administrative Science (JAS), 59-79.

Ngah, I. (2015). Towards sustainable rural development and planning in Malaysia. Retrieved from file://C:/Users/user/Downloads/Chapter1.pdf

Nice, D. C. (1987). Federalism: The politics of intergovernmental relations. United States: St. Martin's Press.

Paige, G. D. (1977). The scientific study of political leadership. New York: The Free Press/Collier MacMillan Publishers.

Parsons, W. (1995). Public policy: An introduction to the theory and practice of policy analysis. Chelthenham: Edward Elgar.

Porter, G. (2013). Transport services and their impact on poverty and growth in rural Sub-Saharan Africa. United Kingdom: University of Durham.

Raja Noriza, R. A. (2006). The implementation of urban transport policy in the Klang Valley, Malaysia. (Doctoral dissertation).

Sabatier, P., \& Mazmanian, D. (1979). The conditions of effective implementation: A guide to accomplishing policy objectives. Policy Analysis, 5(4), 481-504.

Sarkar, A. K., \& Ghosh, D. (2000). Identification and prioritization of access problems in rural areas. Development Southern Africa, 17(1), 149-156. https://doi.org/10.1080/03768350050003479

Silong, A. D., Mohamad, M., Hassan, Z., \& Ariff, I. (2008). Changing roles and competencies for effective public sector leadership. Jurnal Pengurusan Awam, 7(1), 27-46.

Tam, W. Wah. (2008). Developing collaborative leaders for a highly diverse society. Jurnal Pengurusan Awam, 7(1), 47-62. 


\section{Macrothink}

Journal of Public Administration and Governance ISSN 2161-7104 2021, Vol. 11, No. 1

Tsumagari, M. (2007). Rural transport: A review of 15 years of world bank landing from 1992 to 2006. Energy, Water \& Transport Department. Washington, DC: Author.

Weiss, M. L. (2003). Mengatasi politik berasaskan ras di Malaysia: Menentukan norma untuk kerjasama berbilang etnik yang lebih mendalam. In Ho Khai Leong \& James Chin (Eds.) Pentadbiran Mahathir: Prestasi dan Krisis dalam Pemerintahan (edisi Bahasa Melayu) (pp. 68-110). Singapore: Times Media Private Limited.

\section{Copyright Disclaimer}

Copyright for this article is retained by the author(s), with first publication rights granted to the journal.

This is an open-access article distributed under the terms and conditions of the Creative Commons Attribution license (http://creativecommons.org/licenses/by/4.0/). 